\section{O cotidiano como foco de interesse da Bioética: reflexões sobre a prática de pesquisa no território}

\section{Pereira, Camila Claudiano Quina}

Mestrado em Bioética - Univás

camilacquina@gmail.com

Trindade, José Ronaldo

Mestrado em Bioética - Univás

\section{Espíndola, Elizabete Maria}

Mestrado em Bioética - Univás

PALAVRAS-CHAVE: Bioética social; cotidiano; territorio.

O objetivo deste trabalho é discutir e argumentar sobre a relevância de se realizar investigações da bioética no "lugar", no território ou, mais precisamente, no cotidiano. A partir dos estudos sobre a bioética social e do chamado para se pensar pesquisas comprometidas com o contexto brasileiro, o que se propõe é a inserção do/a pesquisador/a no contexto de vida das pessoas para acompanhar o fluxo dos acontecimentos diários e compartilhar das normas e expectativas nos espaços onde a vida acontece. Uma prática comum nas ciências sociais, propõe se metodologias que estimulem o/a pesquisador/a a sair do laboratórios ou salas de portas fechadas e mergulhar nos microlugares: andar pelas ruas, ouvir conversas alheias, observar a arquitetura urbana, os encontros e desencontros, as filas, o trânsito, enfim, observar a cotidianidade. Trata-se de uma prática comprometida com o contexto com o qual se pretende lidar e, consequentemente, que se converta em benefícios para as pessoas que participam do estudo. Consideramos ser uma estratégia interessante para construir conhecimento sobre a vida das pessoas, apreciando a diversidade de acontecimentos psicossociais que ocorrem nos microlugares e, a partir desta experiência, problematizar questões que afetam à vida das pessoas em uma perspectiva bioética, tais como as questões morais que atravessam a existência e produzem efeitos, tais como as desigualdades sociais, as questões de gênero e outras formas de discriminação e exclusão social. Permite ao/à pesquisador/a tornar-se partícipe desses territórios, criar vínculos e, ao analisar as situações cotidianas, conhecer a diversidade de sentidos e significados construídos nas interações sociais. É um convite para estar diante do novo, do inesperado e das singularidades, opondo-se às teorias totalizantes e disciplinadoras. Para embasar esta discussão, pretende-se utilizar os conceitos de cotidiano, microlugares e multiterritorialidades, na interface com a Teoria Ator Rede.

\section{REFERÊNCIAS}

[1] SPINK, M.J. P.Pesquisando no cotidiano: recuperando memórias de pesquisa em Psicologia Social. Psicologia \& Sociedade, v.19, n.1, jan./abr, p. 7-14, 2007.

[2] SPINK, M.J; SPINK, P. Pesquisar o/no cotidiano na pesquisa social: reflexões sobre a noção de lugar, território e redes de associação. Quaestio, Sorocaba, SP, v. 19, n. 3, p. 591-605,dez.2017. 